\title{
Modifications in plasma cholesterol and apolipoproteins of hypercholesterolaemic rats induced by ethanol-soluble factors of Vicia faba
}

\author{
BY ELENA MENGHERI, M. LAURA SCARINO, FRANCESCO \\ VIGNOLINI AND M. ANTONIETTA SPADONI \\ Istituto Nazionale della Nutrizione, Via Ardeatina, 546-00179 Rome, Italy
}

(Received 26 January 1984 - Accepted 1 November 1984)

\begin{abstract}
1. High-fat-high-cholesterol diets containing casein or a Vicia faba bean (faba bean) protein concentrate as the protein source were given to rats for 5 weeks. When the faba bean protein concentrate or its ethanol extract was present in the diet, a marked decrease was found in the level of circulating cholesterol associated with the lower-density lipoproteins (very-low-, intermediate- and low-density lipoproteins) compared with the level found on the diets containing casein or the faba bean protein concentrate deprived of ethanol-soluble factors.

2. Alterations in apoprotein pattern were detected after the different dietary treatments. In particular, apoA-I appeared in an unusual form with electrophoretic mobility faster than normal in all lipoprotein fractions after feeding the diets that did not lower plasma cholesterol. When the diets contained the faba bean protein concentrate or its ethanol extract, the apoA-I disappeared from the lower-density lipoproteins but its normal form and the unusual one were apparent in the high-density lipoproteins.

3. A moderate increase in faecal excretion of acidic steroids was found after feeding the diets containing the ethanol-soluble factors, irrespective of the protein source.

4. The results are discussed in relation to the presence of saponin and polyunsaturated lecithin in the ethanol extract of the faba bean protein concentrate.
\end{abstract}

Many studies conducted on animal models and in humans have suggested that the source of dietary protein influences the level of serum lipids and, in some instances, the course of atherosclerosis. In general, studies on experimental animals have shown that hypercholesterolaemia and atherosclerosis can be induced by diets containing protein from animal sources, whereas a fall in cholesterol occurs with protein from plant sources. In addition, plant protein has the property to lower the level of plasma cholesterol in hypercholesterolaemic humans as well as in experimental animals made hypercholesterolaemic by different treatments (Carrol et al. 1979; Kritchevsky, 1979; Carrol, 1982). The effects of plant proteins on cholesterol and apolipoprotein metabolism have been extensively investigated in order to elucidate the mechanisms involved in the hypocholesterolaemic action (Sugano, 1983). Different components of the protein source such as protein (Carrol, 1982), fibre (Vahouny, 1982), saponins (Oakenfull et al. 1979) and phospholipids (Clark et al. 1981) have been advocated as playing a fundamental role. However, the reason for the different consequences on cholesterol metabolism depending on the type of protein source has yet to be fully ascertained.

In a previous study we have shown that a Vicia faba bean (faba bean) protein concentrate given to hypercholesterolaemic rats caused a significant decrease in plasma cholesterol associated with the lower-density lipoprotein fractions (Jaya et al. 1981), and that this capacity was lost once the faba bean protein concentrate had been extracted with hot ethanol (Mengheri et al. 1982). This finding suggested that neither the protein nor the fibre moiety of the faba bean protein concentrate was involved in the cholesterol-lowering effect.

In the present paper we present evidence that the hot-ethanol extract of the faba bean protein concentrate contains factors which are able to decrease plasma cholesterol and partly restore the altered apoprotein pattern that follows a prolonged load of saturated fat and cholesterol. 
Table 1. Composition of the diets $(\mathrm{g} / \mathrm{kg})$

\begin{tabular}{lrrrrr}
\multicolumn{1}{c}{ Diet* $\ldots$} & $\mathrm{D}_{\mathbf{1}}$ & $\mathrm{D}_{\mathbf{2}}$ & $\mathrm{D}_{3}$ & $\mathrm{D}_{4}$ & $\mathrm{D}_{\mathbf{5}}$ \\
\hline \hline Casein (vitamin free) $\dagger$ & 200 & 100 & 100 & 100 & 200 \\
Vicia faba bean protein concentrate & - & 178 & - & - & - \\
Vicia faba bean protein concentrate & - & - & 140 & 140 & - \\
$\quad$ extracted with hot ethanol§ & & & & & \\
Hot-ethanol extract of Vicia faba & - & - & - & 36 & 36 \\
bean protein concentrate $\|$ & 250 & 250 & 250 & 250 & 250 \\
Coconut oil & 10 & 10 & 10 & 10 & 10 \\
Cholesterol & 5 & 5 & 5 & 5 & 5 \\
Cholic acid & 481 & 403 & 441 & 405 & 445 \\
Sucrose & 4 & 4 & 4 & 4 & 4 \\
Methionine & 10 & 10 & 10 & 10 & 10 \\
Vitamin mixture & 40 & 40 & 40 & 40 & 40 \\
Salt mixture** & & & & & \\
\hline \hline
\end{tabular}

* All diets contained $180 \mathrm{~g}$ protein $/ \mathrm{kg}$.

$\dagger$ From Piccioni Ltd, Brescia, Italy.

$\$$ Contained $562 \mathrm{~g}$ protein (as nitrogen $\times 5 \cdot 7) / \mathrm{kg}$.

$\S$ Contained $642 \mathrm{~g}$ protein $($ as $\mathrm{N} \times 5 \cdot 7) / \mathrm{kg}$.

Obtained by two extractions with $80 \%$ ethanol at $60^{\circ}$ for $12 \mathrm{~h}$, dried under vacuum and lyophilized.

If Composition as described by Hegsted \& Chang (1965).

** Composition as described by Jones \& Foster (1942).

\section{EXPERIMEN T A L}

\section{Dietary treatment}

Male rats (mean weight $150 \mathrm{~g}$ ) of the Sprague-Dawley strain were divided into groups of six animals and fed on one of five diets for 5 weeks. The composition of the diets is given in Table 1. All diets were equally rich in saturated fat $(250 \mathrm{~g} / \mathrm{kg})$ and cholesterol $(10 \mathrm{~g} / \mathrm{kg})$ and contained the same amount of protein either as casein $\left(D_{1}\right.$ and $\left.D_{5}\right)$ or as $50 \%$ casein and $50 \%$ faba bean protein concentrate $\left(D_{2}, D_{3} . D_{4}\right)$ (Table 1$)$. The faba bean protein concentrate incorporated into diets $\mathrm{D}_{3}$ and $\mathrm{D}_{4}$ was previously extracted twice with $80 \%$ ethanol at $60^{\circ}$ for $12 \mathrm{~h}$ to remove the hot-ethanol-soluble factors. The composition of the ethanol extract is given in Table 2. The extract, after evaporation of ethanol under vacuum at $60^{\circ}$, was lyophilized and re-introduced into diet $\mathrm{D}_{4}$ to reconstitute the concentrate. The extract was also added to diet $D_{5}$ to test the effect of the ethanol-soluble factors. An additional group of rats given a standard diet $\left(\mathrm{D}_{6}\right)$ (Piccioni Ltd, Brescia, Italy) was used as normal rats. All animals were housed under constant temperature, humidity and light-dark conditions. Food and water were given ad lib. Food intake was measured weekly and was similar in all the experimental groups.

\section{Plasma lipoprotein isolation and apoprotein analysis}

Following an overnight fast, blood was collected from the thoracic aorta of rats anaesthetized with diethyl ether, and placed into tubes containing EDTA ( $1 \mathrm{~g}$ EDTA/litre blood). Plasma was stored at $4^{\circ}$ in sodium azide $(1 \mathrm{~g} / \mathrm{l})$ for less than $3 \mathrm{~d}$ before isolation of lipoproteins. For each group of animals, two pools of plasma from three rats were made by mixing equal volumes of plasma on the basis of their cholesterol concentration: the largest values were grouped in the first pool, the smallest in the second one. Lipoprotein fractions were separated by sequential density ultracentrifugation (Havel et al. 1955) at $4^{\circ}$ using a Beckman L50 B ultracentrifuge and a $50 \mathrm{Ti}$ rotor. Very-low-density lipoproteins (VLDL) and intermediate-density lipoproteins (IDL) were isolated at $\mathrm{d}<1.0063 \mathrm{~g} / \mathrm{ml}$ and 
Table 2. Composition* of ethanol extract of Vicia faba bean protein concentrate $\dagger$

\begin{tabular}{|c|c|c|c|c|c|}
\hline Major constituents & $\mathrm{g} / \mathrm{kg}$ & Fatty acid & $\mathrm{mmol} / \mathrm{mol}$ & Amino acid & $\mathrm{g} / \mathrm{kg} \mathrm{N}$ \\
\hline Total lipids & 482 & $14: 0$ & $4 \cdot 8$ & Lysine & $22 \cdot 5$ \\
\hline Total nitrogen & 43 & $15: 0$ & $3 \cdot 1$ & Histidine & $19 \cdot 4$ \\
\hline Phospholipids & 186 & $16: 0$ & 213.6 & Arginine & $512 \cdot 2$ \\
\hline Amino acids & 41 & $17: 0$ & $3 \cdot 9$ & Aspartic acid & $191 \cdot 1$ \\
\hline Saponin & 62 & $18: 0$ & $51 \cdot 2$ & Threonine & $21 \cdot 5$ \\
\hline Vicine + convicine & 152 & $18: 1$ & 270.7 & Serine & $72 \cdot 8$ \\
\hline \multirow{11}{*}{ Ash } & 37 & $18: 2$ & $401 \cdot 1$ & Glutamic acid & $197 \cdot 2$ \\
\hline & & $18: 3$ & $23 \cdot 3$ & Proline & $124 \cdot 3$ \\
\hline & & $20: 1$ & $1 \cdot 4$ & Glycine & $102 \cdot 5$ \\
\hline & & $21: 1$ & $5 \cdot 5$ & Alanine & $43 \cdot 7$ \\
\hline & & $X \ddagger$ & $2 \cdot 8$ & Cysteine & $101 \cdot 8$ \\
\hline & & $20: 4$ & $1 \cdot 0$ & Valine & 61.9 \\
\hline & & $20: 5$ & $11 \cdot 1$ & Methionine & $23 \cdot 7$ \\
\hline & & $24: 1$ & 4.6 & Isoleucine & $71 \cdot 2$ \\
\hline & & $22: 4$ & 1.8 & Leucine & $42 \cdot 8$ \\
\hline & & & & Tyrosine & $245 \cdot 9$ \\
\hline & & & & Phenylalanine & $72 \cdot 5$ \\
\hline
\end{tabular}

* For analysis, see below.

$\dagger$ Obtained by two extractions with $80 \%$ ethanol at $60^{\circ}$ for $12 \mathrm{~h}$, dried under vacuum and lyophilized.

$\ddagger$ Unidentified.

$\mathrm{d}<1.020 \mathrm{~g} / \mathrm{ml}$ respectively after centrifuging at $100000 \mathrm{~g}$ for $20 \mathrm{~h}$. Low-density lipoproteins $(\mathrm{LDL})$ and high-density lipoproteins $\left(\mathrm{HDL}_{1}, \mathrm{HDL}_{2}\right)$ were isolated at $\mathrm{d}<1.050, \mathrm{~d}<1.090$ and $\mathrm{d}<1.2 \mathrm{~g} / \mathrm{ml}$ respectively after centrifuging at $100000 \mathrm{~g}$ for $30 \mathrm{~h}$. All lipoprotein fractions were washed once and then extensively dialyzed at $4^{\circ}$ against saline $(9 \mathrm{~g}$ sodium chloride/1)-EDTA $(0 \cdot 1 \mathrm{~g} / \mathrm{l}), \mathrm{pH} 7 \cdot 4$.

Isolated lipoprotein fractions were delipidated using sodium dodecyl sulphate $(40 \mathrm{~g} / \mathrm{l}$; SDS) and apoproteins were analysed by SDS-polyacrylamide gel electrophoresis using $12 \%$ acrylamide according to the method of Laemmly (1970).

\section{Chemical analysis of plasma lipoproteins}

Total cholesterol and triglycerides were determined enzymically using a Beckman cholesterolES and triglycerides-INT reagent kit in a Beckman autoanalyser (Trace III Chemistry System; Beckman Instruments Inc.).

Proteins were determined by the method of Lowry et al. (1951).

\section{Collection of faeces and analysis}

Faeces were collected daily during the last week of the experimental period and stored at $-80^{\circ}$ until analysed. They were dried over phosphorus pentoxide for $48 \mathrm{~h}$, ground and extracted with hot ethanol $(20: 1, \mathrm{w} / \mathrm{v})$. Cholesterol was determined by the method of Rudel \& Morris (1973), cholic and deoxycholic acids by the procedure of Mosbach et al. (1954).

\section{Analysis of ethanol extract}

Lipids were exhaustively extracted with diethyl ether in a Soxhlet apparatus, dried under nitrogen and weighed.

Methyl esters of fatty acids were prepared by micro-esterification (Metcalpe \& Schmitz, 1961) and separated using a Perkin Elmer F30 gas-chromatograph. 
Table 3. Effect of different dietary treatments on plasma cholesterol and triglycerides $(m g / l)$

(Mean values with their standard errors for six rats)

\begin{tabular}{lllllr}
\hline & \multicolumn{2}{c}{ Cholesterol } & & \multicolumn{2}{c}{ Triglyceride } \\
\cline { 2 - 3 } \cline { 5 - 6 } Diet* & Mean & SE & & Mean & SE \\
\hline$D_{1}$ & $2212^{\mathbf{a}}$ & 203 & & 954 & 128 \\
$\mathrm{D}_{2}$ & $1700^{\mathbf{a}, \mathrm{d}, \mathrm{e}}$ & 99 & & 954 & 83 \\
$\mathrm{D}_{3}$ & $2290^{\mathbf{a}}$ & 214 & & 973 & 83 \\
$\mathrm{D}_{4}$ & $1095^{\mathbf{a}, \mathrm{b}, \mathrm{c}}$ & 102 & & 1097 & 73 \\
$\mathrm{D}_{5}$ & $1563^{\mathbf{3}, \mathrm{i}, \mathrm{B}}$ & 206 & & 802 & 65 \\
$\mathrm{D}_{\mathbf{6}}$ (standard) & 553 & 33 & & 984 & 72 \\
\hline \hline
\end{tabular}

Values were significantly different (Mann-Whitney test): ${ }^{a} \operatorname{diets} \mathrm{D}_{1}+\mathrm{D}_{2}+\mathrm{D}_{3}+\mathrm{D}_{4}+\mathrm{D}_{5} v$. $\mathrm{D}_{6}$ (standard) $(P=0.001) ;{ }^{\mathrm{b}} \operatorname{diet} \mathrm{D}_{4} v$. diets $\mathrm{D}_{1}+\mathrm{D}_{3}(P=0.001) ;{ }^{\mathrm{c}} \operatorname{diet} \mathrm{D}_{4} v$. diets $\mathrm{D}_{2}+\mathrm{D}_{5}(P<0.005) ;{ }^{\mathrm{d}} \operatorname{diet} \mathrm{D}_{2} v$. diet $\mathrm{D}_{1}$ $(P<0.0025)$; ${ }^{e} \operatorname{diet} \mathrm{D}_{2} v$. diet $\mathrm{D}_{3}(P<0.05) ;^{\mathrm{P}} \operatorname{diet} \mathrm{D}_{5} v$. diet $\mathrm{D}_{1}(P=0.025)$; ${ }^{\mathrm{g}}$ diet $\mathrm{D}_{5} v . \operatorname{diet} \mathrm{D}_{3}(P<0.05)$.

* For details, see Table 1.

Phospholipids were determined as phosphate (Kuttner \& Lichtenstein, 1930) after digestion with $60 \%$ perchloric acid.

Total $\mathrm{N}$ was determined in delipidated extract by the Kjeldahl procedure and amino acids were analysed after acid-hydrolysis (Moore \& Stein, 1963) in a Beckman amino acid analyser (model 120C). For analysis of cysteine and methionine, a performic acid oxidation was performed before the hydrolysis (Schram et al. 1954).

Saponins were determined by thin-layer chromatography (TLC) by the method of Fenwick \& Oakenfull (1981).

Vicine and convicine were extracted with $65 \%$ hot ethanol, separated by TLC using cellulose plates and eluted with saturated $\left(\mathrm{NH}_{4}\right)_{2} \mathrm{SO}_{4}-1$ M-sodium acetate-propan-2-ol (80:18:2, by vol.) (Carnovale et al. 1985).

\section{Statistical analysis}

Significance of differences between groups was determined by Student's $t$ test and by Mann-Whitney test (Conover, 1971).

\section{RESULTS}

\section{Cholesterol and protein distribution among lipoprotein fractions}

The hypercholesterolaemia induced in rats given a high-fat, high-cholesterol, casein $\operatorname{diet}\left(\mathrm{D}_{1}\right)$ was partly reduced when the faba bean protein concentrate replaced $50 \%$ of the casein in the diet $\left(\mathrm{D}_{2}\right)$ (Table 3). The faba bean protein concentrate deprived of hot-ethanol-soluble factors $\left(D_{3}\right)$ failed to induce any decrease in cholesterol level, whereas once reconstituted $\left(D_{4}\right)$, it was again able to reduce plasma cholesterol to a level even lower than that obtained with diet $\mathrm{D}_{2}$. Furthermore, the addition of ethanol extract to the hypercholesterolaemiccasein diet $\left(D_{5}\right)$ indicated that the ethanol extract itself had the property to decrease the level of plasma cholesterol.

Unlike cholesterol, plasma triglycerides did not change after feeding the different diets.

The distribution of cholesterol among the lipoprotein fractions was markedly altered in all experimental groups (Table 4). In rats given diet $\mathrm{D}_{1}$ a dramatic accumulation of cholesterol in VLDL, IDL and LDL occurred, while less cholesterol was associated with lipoproteins in the HDL-density range compared with normal rats. By inclusion of the faba 
Table 4. Effect of dietary treatment on distribution of cholesterol in plasma lipoprotein fractions $(\mathrm{mg} / \mathrm{l})$

(Each value represents a pool of plasma from three rats. Equal volumes of plasma were pooled on the basis of their cholesterol concentration: the largest values were grouped in the first pool, the smallest in the other one)

\begin{tabular}{|c|c|c|c|c|c|}
\hline Diet* & VLDL & IDL & LDL & $\mathrm{HDL}_{\mathbf{1}}$ & $\mathrm{HDL}_{2}$ \\
\hline $\mathrm{D}_{1}$ & $\begin{array}{l}1324 \\
1082\end{array}$ & $\begin{array}{l}432 \\
497\end{array}$ & $\begin{array}{l}174 \\
174\end{array}$ & $\begin{array}{l}62 \\
56\end{array}$ & $\begin{array}{l}95 \\
71\end{array}$ \\
\hline $\mathrm{D}_{2}$ & $\begin{array}{l}775 \\
666\end{array}$ & $\begin{array}{l}372 \\
399\end{array}$ & $\begin{array}{l}184 \\
178\end{array}$ & $\begin{array}{l}36 \\
49\end{array}$ & $\begin{array}{l}209 \\
214\end{array}$ \\
\hline$D_{3}$ & $\begin{array}{l}1151 \\
1055\end{array}$ & $\begin{array}{l}430 \\
582\end{array}$ & $\begin{array}{l}223 \\
321\end{array}$ & $\begin{array}{r}57 \\
104\end{array}$ & $\begin{array}{r}98 \\
166\end{array}$ \\
\hline $\mathrm{D}_{4}$ & $\begin{array}{l}415 \\
338\end{array}$ & $\begin{array}{l}248 \\
256\end{array}$ & $\begin{array}{l}114 \\
131\end{array}$ & $\begin{array}{l}37 \\
71\end{array}$ & $\begin{array}{l}212 \\
218\end{array}$ \\
\hline$D_{5}$ & $\begin{array}{l}790 \\
523\end{array}$ & $\begin{array}{l}379 \\
278\end{array}$ & $\begin{array}{l}148 \\
119\end{array}$ & $\begin{array}{l}45 \\
38\end{array}$ & $\begin{array}{l}172 \\
205\end{array}$ \\
\hline $\mathrm{D}_{6}$ (standard) & $\begin{array}{l}78 \\
43\end{array}$ & $\begin{array}{l}26 \\
15\end{array}$ & $\begin{array}{l}56 \\
42\end{array}$ & $\begin{array}{l}111 \\
119\end{array}$ & $\begin{array}{l}269 \\
248\end{array}$ \\
\hline
\end{tabular}

VLDL, very-low-density lipoprotein; IDL, intermediate-density lipoprotein; LDL, low-density lipoprotein; $\mathrm{HDL}_{1}$ and $\mathrm{HDL}_{2}$, high-density lipoprotein.

* For details, see Table 1.

bean protein concentrate in diet $\mathrm{D}_{2}$, the VLDL-cholesterol and, to a lesser extent, the IDL-cholesterol, were reduced compared with levels in rats given diet $D_{1}$, whereas HDL-cholesterol remained almost at the normal level. After feeding diets $\mathrm{D}_{4}$ and $\mathrm{D}_{5}$, in which the ethanol-soluble factors were added, the cholesterol distribution in lipoproteins was similar to that found after feeding diet $\mathrm{D}_{2}$, with a decrease in VLDL-cholesterol particularly evident after giving diet $D_{4}$. The inability of diet $D_{3}$ to lower plasma cholesterol was reflected in a cholesterol-lipoprotein distribution similar to that found with diet $D_{1}$. The statement that the groups are different is supported by the fact that the highest values for VLDL and IDL with diets $\mathrm{D}_{2}, \mathrm{D}_{4}$ and $\mathrm{D}_{5}$ were always lower than the smallest values with diets $\mathrm{D}_{1}$ and $\mathrm{D}_{3}$ respectively, while the converse occurred for $\mathrm{HDL}_{2}$.

The distribution of protein among the lipoprotein fractions was also modified by the different dietary treatments (Table 5). A noticeable increase in the amount of protein associated with VLDL and IDL and, to a lesser extent, with LDL, was apparent in all experimental groups compared with normal rats, whereas the protein components of $\mathrm{HDL}_{1}$ and $\mathrm{HDL}_{2}$ were reduced. Moreover, compared with diet $\mathrm{D}_{1}$, the protein content decreased in VLDL after giving diet $\mathrm{D}_{4}$ as well as in IDL and LDL after giving diets $\mathrm{D}_{2}, \mathrm{D}_{4}$ and $\mathrm{D}_{5}$, while it was higher in $\mathrm{HDL}_{2}$ after giving diets $\mathrm{D}_{2}, \mathrm{D}_{4}$ and $\mathrm{D}_{5}$.

The ratio, cholesterol:protein of the lower-density lipoproteins was higher in the experimental groups than in normal rats, and was almost double in VLDL and IDL (Table 6); however, it was virtually unmodified in the HDL fractions, owing to the similar trend of cholesterol and protein content.

\section{Characterization of apoproteins by gel electrophoresis}

Polyacrylamide gel electrophoresis of plasma lipoproteins (Plates 1 and 2) revealed alterations in the pattern of apoproteins induced by the different diets. ApoE with new isoforms appeared prominently in VLDL, IDL and LDL in all dietary treatments. 
Table 5. Effect of dietary treatment on distribution of protein in plasma lipoprotein fractions $(\mathrm{mg} / \mathrm{l})$

(Each value represents a pool of plasma from three rats. Equal volumes of plasma were pooled on the basis of their cholesterol concentration: the largest values were grouped in the first pool, the smallest in the other one)

\begin{tabular}{lcccccc}
\hline \hline & Diet* & VLDL & IDL & LDL & HDL $_{1}$ & HDL $_{2}$ \\
\hline $\mathrm{D}_{1}$ & 258 & 72 & 85 & 33 & 257 \\
& 141 & 77 & 45 & 31 & 181 \\
$\mathrm{D}_{2}$ & 222 & 58 & 71 & 15 & 407 \\
& 124 & 56 & 57 & 20 & 354 \\
& $\mathrm{D}_{3}$ & 64 & 104 & 33 & 251 \\
& 134 & 78 & 104 & 49 & 310 \\
$\mathrm{D}_{4}$ & 140 & 39 & 36 & 15 & 443 \\
& 102 & 48 & 37 & 26 & 436 \\
& 99 & 54 & 43 & 22 & 383 \\
$\mathrm{D}_{5}$ & 213 & 48 & 66 & 17 & 402 \\
& 105 & $7 \cdot 5$ & 35 & 50 & 548 \\
$\mathrm{D}_{6}$ (standard) & 38 & $7 \cdot 0$ & 20 & 60 & 578 \\
& 29 & & & \\
\end{tabular}

VLDL, very-low-density lipoprotein; IDL, intermediate-density lipoprotein; LDL, low-density lipoprotein; $\mathrm{HDL}_{1}$ and $\mathrm{HDL}_{2}$, high-density lipoprotein.

* For details, see Table 1 .

Conversely, apoE decreased in $\mathrm{HDL}_{1}$ and it was not detectable in $\mathrm{HDL}_{2}$ after giving any of the experimental diets $\left(D_{1}-D_{5}\right)$. A band corresponding to apoA-I was found in VLDL, IDL and LDL after giving diets $D_{1}$ and $D_{3}$ but it was barely detectable in the same lipoproteins with diets $\mathrm{D}_{2}, \mathrm{D}_{4}$ and $\mathrm{D}_{5}$. Moreover, an apoA-I which migrated faster than the normal apoprotein appeared in $\mathrm{HDL}_{2}$, with all dietary treatments. This band had the same electrophoretic mobility as the apoA-I detected in the lower-density lipoproteins (Plate $2 b$ ). Besides this new form, the normal apoA-I was also present in $\mathrm{HDL}_{2}$ following the feeding of diets $D_{2}, D_{4}$ and $D_{5}$. ApoA-I was more evident in $H D L_{1}$ in rats on dietary treatments $D_{1}-D_{5}$ compared with normal rats, and appeared to have the same electrophoretic mobility as the faster-moving band of apoA-I in $\mathrm{HDL}_{2}$. This anomalous apoA-I cannot be considered an artefact because it was present only in the lower-density lipoproteins following the feeding of diets $D_{1}$ and $D_{3}$, i.e. the two diets unable to lower the plasma cholesterol. Moreover, it cannot be identified as a proform of apoA-I (Ghiselli et al. 1983) which migrates more slowly than the mature apoA-I.

The apoC apoproteins were not always well resolved in the SDS-polyacrylamide gels used. They appeared in VLDL with two of the three normal bands and with a prominent band in $\mathrm{HDL}_{2}$ irrespective of the dietary treatment.

\section{Faecal excretion of steroids}

Table 7 shows the excretion of acidic steroids and cholesterol. Rats that received diets $D_{2}$, $D_{4}$ and $D_{5}$ excreted a larger amount of cholic acid than those given diets $D_{1}$ and $D_{3}$. Owing to the variability of the values, only the differences between diet $D_{1}$ and diets $D_{2}, D_{4}$ and $\mathrm{D}_{5}$ were significant. A moderate increase in cholesterol excretion was apparent after feeding diets $D_{2}, D_{3}$ and $D_{4}$ whereas no difference was seen with diet $D_{5}$, compared with rats given $\operatorname{diet} \mathbf{D}_{1}$. 
Table 6. Effect of dietary treatment on the ratio, cholesterol:protein in plasma lipoprotein fractions

(Each value represents a pool of plasma from three rats. Equal volumes of plasma were pooled on the basis of their cholesterol concentration: the largest values were grouped in the first pool, the smallest in the other one)

\begin{tabular}{|c|c|c|c|c|c|}
\hline Diet* & VLDL & IDL & LDL & $\mathrm{HDL}_{\mathbf{1}}$ & $\mathrm{HDL}_{2}$ \\
\hline $\mathrm{D}_{1}$ & $\begin{array}{l}51 \\
77\end{array}$ & $\begin{array}{l}60 \\
65\end{array}$ & $\begin{array}{l}20 \\
39\end{array}$ & $\begin{array}{l}19 \\
18\end{array}$ & $\begin{array}{l}3.7 \\
3.9\end{array}$ \\
\hline $\mathrm{D}_{2}$ & $\begin{array}{l}35 \\
54\end{array}$ & $\begin{array}{l}64 \\
71\end{array}$ & $\begin{array}{l}26 \\
31\end{array}$ & $\begin{array}{l}24 \\
24\end{array}$ & $\begin{array}{l}5 \cdot 1 \\
6 \cdot 0\end{array}$ \\
\hline $\mathrm{D}_{3}$ & $\begin{array}{l}86 \\
75\end{array}$ & $\begin{array}{l}67 \\
76\end{array}$ & $\begin{array}{l}21 \\
31\end{array}$ & $\begin{array}{l}18 \\
21\end{array}$ & $\begin{array}{l}3 \cdot 9 \\
5 \cdot 3\end{array}$ \\
\hline $\mathrm{D}_{4}$ & $\begin{array}{l}41 \\
34\end{array}$ & $\begin{array}{l}63 \\
53\end{array}$ & $\begin{array}{l}32 \\
35\end{array}$ & $\begin{array}{l}25 \\
27\end{array}$ & $\begin{array}{l}4 \cdot 8 \\
5 \cdot 0\end{array}$ \\
\hline $\mathbf{D}_{5}$ & $\begin{array}{l}37 \\
49\end{array}$ & $\begin{array}{l}70 \\
58\end{array}$ & $\begin{array}{l}34 \\
18\end{array}$ & $\begin{array}{l}20 \\
22\end{array}$ & $\begin{array}{l}4 \cdot 4 \\
5 \cdot 0\end{array}$ \\
\hline $\mathrm{D}_{6}$ (standard) & $\begin{array}{l}20 \\
15\end{array}$ & $\begin{array}{l}37 \\
21\end{array}$ & $\begin{array}{l}16 \\
21\end{array}$ & $\begin{array}{l}22 \\
20\end{array}$ & $\begin{array}{l}4 \cdot 9 \\
4 \cdot 2\end{array}$ \\
\hline
\end{tabular}

VLDL, very-low-density lipoprotein; IDL, intermediate-density lipoprotein; LDL, low-density lipoprotein; $\mathrm{HDL}_{1}$ and $\mathrm{HDL}_{2}$, high-density lipoprotein.

* For details, see Table 1.

Table 7. Excretion of cholic acid, deoxycholic acid and cholesterol ( $m g / d$ per rat) after different dietary treatments

(Mean values with their standard error for six rats)

\begin{tabular}{|c|c|c|c|c|c|c|}
\hline \multirow[b]{2}{*}{ Diet* } & \multicolumn{2}{|c|}{ Cholic acid } & \multicolumn{2}{|c|}{ Deoxycholic acid } & \multicolumn{2}{|c|}{ Cholesterol } \\
\hline & Mean & SE & Mean & SE & Mean & SE \\
\hline $\mathrm{D}_{1}$ & $34 \cdot 7^{a}, c, d$ & $2 \cdot 0$ & $24 \cdot 1$ & $2 \cdot 4$ & $68 \cdot 8^{\mathrm{a}}$ & $5 \cdot 4$ \\
\hline $\mathrm{D}_{2}$ & $44 \cdot 8^{\mathrm{a}}$ & $4 \cdot 6$ & $24 \cdot 0$ & $1 \cdot 4$ & $90 \cdot 0^{a, b}$ & $5 \cdot 2$ \\
\hline $\mathrm{D}_{3}$ & $38 \cdot 7$ & $2 \cdot 9$ & $24 \cdot 6$ & $1 \cdot 3$ & $79 \cdot 6$ & $4 \cdot 7$ \\
\hline $\mathrm{D}_{4}$ & $48 \cdot 4^{\mathrm{c}}$ & $2 \cdot 2$ & $27 \cdot 9$ & 1.9 & 81.9 & $5 \cdot 7$ \\
\hline$D_{5}$ & $48 \cdot 7^{d}$ & $5 \cdot 7$ & $27 \cdot 3$ & 1.6 & $65 \cdot 7^{\mathrm{b}}$ & $6 \cdot 0$ \\
\hline
\end{tabular}

$a, b, c, d$ Values within the same column sharing a common superscript letter were significantly different (Student's $t$ test): ${ }^{\mathrm{a}} P<0.05,{ }^{\mathrm{b}} P<0.02, \mathrm{c}, \mathrm{d} P<0.01$.

* For details, see Table 1 .

\section{DISCUSSION}

The results in the present paper indicate that rats chronically fed on a diet rich in saturated fat and cholesterol, and containing casein as the protein source, developed a high level of plasma cholesterol in postabsorptive conditions while maintaining a normal level of triglycerides. This differential response of the two lipid components was accompanied by modifications in the composition of plasma lipoproteins. The main modification was the appearance of apoA-I with an electrophoretic mobility faster than the normal apoA-I in the lower density lipoproteins (VLDL, IDL, LDL) as well as in the higher-density lipoproteins $\left(\mathrm{HDL}_{1}, \mathrm{HDL}_{2}\right)$. It is well documented that an abnormal lipoprotein (lipoprotein$X)$ containing apoA-I, apoE and apoC as apoproteins (Seidel et al. 1969) is found in the 
flotation area of LDL in cholestatic liver disease and in lecithin-cholesterol acyltransferase (CAT; EC 2.3. I.43) deficiency, and it can also be induced in experimental animals by cholesterol feeding (Glomset \& Norum, 1973; Patsch et al. 1977). The appearance of this anomalous lipoprotein was attributed to the inbalance between an increased removal of the triglyceride core by lipoprotein lipase (LPL; EC 3. I I . 3) and a diminished removal of surface components by LCAT. This results in an excess of surface components rich in unesterified cholesterol and apoproteins. Moreover, in vitro studies on human lymph chylomicrons have also shown that numerous collapsed particles with redundant surfaces as well as smaller particles within the LDL and HDL density range appeared following incubation with LPL (Schaefer et al. 1982). Based on the above observations, the unusual lipoprotein pattern found under these experimental conditions can be attributed to the progressive hydrolysis of the triglyceride-rich core of chylomicrons and possibly of VLDL, leading to an accumulation of apoA-I-containing particles floating in the region of the lower-density lipoproteins. The fact that the apoA-I was present in an anomalous form supports this hypothesis because it cannot act properly as an activator of LCAT (Fielding et al. 1972). It is difficult to explain from our findings where an unusual apoA-I was formed and the reason for its appearance. Moreover, the following findings suggest an intestinal origin for the apoA-I: a fat-load stimulates the synthesis of apoA-I in the intestine (Glickman \& Green, 1977) and changes the pattern of apoA-I isoforms in lymph chylomicrons and in VLDL (Ghiselli et al. 1983) which are, together with HDL, the carriers for secretion of apoA-I (Green et al. 1978; Wu \& Windmueller, 1978). ApoA-I is a major apoprotein of HDL of rat intestine where $50 \%$ of the apoA-I of the total body is synthesized (Wu \& Windmueller, 1979); the plasma $\mathrm{HDL}_{2}$ found under our experimental conditions contained large amounts of apoA-I but no apoE, which characterizes the $\mathrm{HDL}_{2}$ originating from liver (Nicholl et al. 1979; Tall \& Small, 1979).

It has been demonstrated recently that the conversion of the proform of apoA-I (proapoA-I) to mature apoA-I is effected by an enzyme in circulating plasma (Edelstein et al. 1983). We can speculate that the apoA-I-rich particles leaving the intestine, since they are rich in cholesterol and saturated fat, are altered in their physico-chemical structure, which does not allow the normal proteolytic processing of proapoA-I. The converting enzyme may then cleave the proapoA-I at a different site from normal to give a smaller apoA-I.

The incorporation of the faba bean protein concentrate or of its ethanol extract in a hypercholesterolaemic-casein diet resulted in a decrease in plasma cholesterol and in a reduction of some of the described alterations in lipoprotein pattern. Of particular relevance was the disappearance of the anomalous apoA-I from the lower-density lipoproteins and the appearance of the normal form of apoA-I in $\mathrm{HDL}_{2}$. The mechanism that triggers these modifications cannot be ascribed to a diminished cholesterol absorption. In fact, a moderate increase in excretion of cholesterol was found after giving the faba bean protein concentrate $\left(D_{2}\right)$, but it was also found after giving the diet devoid of ethanol-soluble factors $\left(D_{3}\right)$ which did not lower the plasma cholesterol. Moreover, after addition of these ethanol-soluble factors to the hypercholesterolaemic casein diet $\left(D_{5}\right)$, the cholesterol absorption did not change. On the contrary, the increase in the excretion of acidic steroids observed exclusively after giving diets containing ethanol-soluble factors, although moderate, could result in a larger conversion of liver cholesterol into bile acids and therefore in a reduction of circulating cholesterol. Saponin, one of the components of the ethanol extract of faba beans, may have acted in reducing the intestinal absorption of bile acids (Sautier et al. 1979; Topping et al 1980). However, it is unlikely that this mechanism alone is responsible for the overall decrease in cholesterol and for the normal formation of apoA-I. The ethanol extract of the faba bean protein concentrate contains a high percentage of polyunsaturated fatty acids (about $44 \%$ of total fatty acids). Therefore the phospholipids present in the 
extract should be highly polyunsaturated. Moreover, these phospholipids are represented predominantly by lecithin and by a very small amount of phosphatidylethanolamine, as detected by TCL (values not shown). Polyunsaturated lecithin has been shown to have a hypocholesterolaemic effect (Wong et al. 1980; O’Mullane \& Hawthorne, 1982). However, it is not yet clear how this action is brought about. In the lumen of the small intestine, lecithin can be completely hydrolysed, converted into lysolecithin and fatty acid or absorbed intact (Lekim, 1976). In the mucosal cell, lysolecithin can be re-esterified with a fatty acid to form lecithin and then incorporated into chylomicrons and VLDL (Scow et al. 1967). Thus it is possible that the polyunsaturated lecithin of the faba bean ethanol extract escapes complete hydrolysis and favours the formation of more unsaturated chylomicronphospholipids (Rosseneu et al. 1979) which would improve the metabolism of cholesterol, as they are a better substrate for LCAT activity (Assmann, 1976). We can also hypothesize that a more suitable arrangement of surface components in chylomicrons and VLDL caused by polyunsaturated lecithin would allow the correct processing of proapoA-I towards the mature form of apoA-I. Hence, the apoA-I in the normal form would enhance LCAT activity. The findings reported here on the disappearance of apoA-I-containing particles floating in the region of the lower-density lipoproteins are compatible with this mechanism, because LCAT activity would balance LPL activity and therefore facilitate the removal of surface components.

The authors are grateful to Dr D. Oakenfull (CSIRO Division of Food Research, North Ryde, NSW 2113, Australia) for his kind help in analysing saponins. The present research work was supported by CNR, Italy, Special grant I.P.R.A. Sub-project 3, Paper N 109.

\section{REFEREN CES}

Assmann, G. (1976). In Phosphatidylcholine, pp. 34-47 [H. Peeters, editor]. Berlin, Heidelberg, New York: Springer-Verlag.

Carnovale, E., Cappelloni, M., Zaza, G. \& Ibba, P. (1985). Qualitas Plantarum-Plant Foods for Human Consumption (In the Press).

Carrol, K. K. (1982). Federation Proceedings 41, 2792-2796.

Carrol, K. K., Huff, M. W. \& Roberts, D. C. K. (1979). In Soy Protein and Human Nutrition, pp. 261-280 [H. L. Wilcke, D. T. Hopkins and D. H. Waggle, editors]. New York: Academic Press.

Clark, S. B., Clark, V. E. \& Small, D. M. (1981). American Journal of Physiology 241, G422-G430.

Conover, W. J. (1971). In Practical Non-Parametric Statistics, pp. 223-237. New York: J. Wiley \& Sons.

Edelstein, C., Gordon, J. I., Toscas, K., Sims, H. F., Strauss, A. W. \& Scanu, A. M. (1983). Journal of Biological Chemistry 258, $11430-11433$.

Fenwick, D. E. \& Oakenfull, D. (1981). Journal of Agriculture and Food Chemistry 32, 273-278.

Fielding, C. J., Shore, V. G. \& Fielding, P. E. (1972). Biochimica et Biophysica Acta 270, 513-518.

Ghiselli, G., Schafer, E. J., Light, J. A. \& Brewer, B. (1983). Journal of Lipid Research 24, 731-736.

Glickman, R. M. \& Green, P. H. R. (1977). Proceedings of National Academy of Sciences, USA 74, $2569-2573$.

Glomset, J. A. \& Norum, K. R. (1973). Advances in Lipid Research 11, 1-65.

Green, P. H. R., Tall, A. R. \& Glickman, R. M. (1978). Journal of Clinical Investigation 61, 528-534.

Havel, R. J., Eder, H. A. \& Bragdon, J. H. (1955). Journal of Clinical Investigation 34, 1345-1353.

Hegsted, D. M. \& Chang, X. (1965). Joumal of Nutrition 85, 159-168.

Jaya, T. V., Mengheri, E., Scarino, M. L., Vignolini, F. \& Spadoni, M. A. (1981). Nutrition Reports International 23, 55-69.

Jones, J. H. \& Foster, J. (1942). Journal of Nutrition 24, 345-352.

Kritchevsky, D. (1979). Journal American Oil Chemists' Society 56, 135-140.

Kuttner, T. \& Lichtenstein, L. (1930). Journal of Biological Chemistry 83, 671-676.

Laemmly, U. K. (1970). Nature 227, 680-685.

Lekim, D. (1976). In Phosphatidylcholine, pp. 48-65 [H. Peeters, editors]. Berlin, Heidelberg, New York: Springer-Verlag. Lowry, O. H., Rosebrough, N. J., Farr, A. L. \& Randall, R. J. (1951). Journal of Biological Chemistry 193,
265-275.

Mengheri, E., Scarino, M. L., Vignolini, F. \& Spadoni, M. A. (1982). Nutrition Reports International 26, 751-758. 
Metcalpe, L. D. \& Schmitz, A. A. (1961). Analytical Chemistry 33, 363-364.

Moore, S. \& Stein, W. H. (1963). In Methods in Enzymology, vol. 6, pp. 819-831 [S. P. Colowich and N. O. Kaylan, editors]. New York and London: Academic Press.

Mosbach, E. H., Kalinsky, H. J., Halpern, E. \& Kendall, F. E. (1954). Archives of Biochemistry and Biophysics $51,402-410$.

Nicoll, A., Miller, N. E. \& Lewis, B. (1979). Advances in Lipid Research 17, 53-106.

Oakenfull, D. G., Fenwick, D. E. \& Hood, R. L. (1979). British Journal of Nutrition 40, 299-309.

O'Mullane, J. E. \& Hawthorne, J. (1982). Atherosclerosis 45, 81-90.

Patsch, J. R., Aune, K. C., Gotto, A. M. Ir \& Morriset, J. D. (1977). Journal of Biological Chemistry 252, 2113-2120.

Rosseneu, M., Declercq, B., Vandamme, D., Vercaemst, R., Soetewey, F., Peters, H. \& Blaton, V. (1979). Atherosclerosis 32, 141-153.

Rudel, L. L. \& Morris, M. D. (1973). Journal of Lipid Research 14, 364-366.

Sautier, C., Doucet, C., Flament, C. \& Lemonnier, D. (1979). Atherosclerosis 34, $233-241$.

Schaefer, E. J., Wetzel, M. G., Bengtsson, G., Scow, R. O., Brewer, H. B. Jr \& Olivecrona, T. (1982). Journal of Lipid Research 23, 1259-1273.

Schram, E., Moore, S. \& Bigwood, E. J. (1954). Biochemical Journal 57, 33-37.

Scow, R. O., Stein, Y. \& Stein, O. (1967). Journal of Biological Chemistry 242, 4919-4924.

Seidel, D., Alaupovic, P. \& Furman, R. H. (1969). Journal of Clinical Investigation 48, 1211-1223.

Sugano, M. (1983). In Current Topics in Nutrition and Disease. Animal and Vegetable Proteins in Lipid Metabolism and Atherosclerosis, vol. 8, pp. 51-84 [M. J. Gibney and D. Kritchevsky, editors]. New York: Alan R. Liss, Inc.

Tall, A. R. \& Small, D. M. (1979). Advances in Lipid Research 17, 1-51.

Topping, D. L., Storer, G. B., Calvert, G. D., Illman, R. J., Oakenfull, D. G. \& Weller, R. A. (1980). American Journal of Clinical Nutrition 33, 783-786.

Vahouny, G. V. (1982). Federation Proceedings 41, 2801-2806.

Wong, E. K., Nicolosi, R. J., Low, P. A., Herd, J. A. \& Hayes, K. C. (1980). Lipids 15, 428-433.

Wu, A. L. \& Windmueller, H. G. (1978). Journal of Biological Chemistry 253, 2525-2528.

Wu, A. L. \& Windmueller, H. G. (1979). Journal of Biological Chemistry 254, 7316-7322.

\section{EXPLANATION OF PLATES}

Plate 1. Sodium dodecyl sulphate-polyacrylamide gel electrophoresis of apoproteins of very-low-, intermediateand low-density lipoproteins (VLDL, IDL and LDL respectively) after feeding the five experimental diets $\left(\mathrm{D}_{1}-\mathrm{D}_{5}\right)$ or the standard diet $\left(D_{6}\right)$. Apoproteins were identified by the use of standard molecular weights.

For composition of the diets, see Table 1.

Plate 2. Sodium dodecyl sulphate-polyacrylamide gel electrophoresis of apoproteins of: (a) high-density lipoprotein $\left(\mathrm{HDL}_{1}\right.$ and $\left.\mathrm{HDL}_{2}\right)$ after feeding the five experimental diets $\left(\mathrm{D}_{1}-\mathrm{D}_{5}\right)$ or the standard diet $\left(\mathrm{D}_{6}\right),(b)$ all lipoprotein fractions after feeding the diet $D_{1}$. Apoproteins were identified by the use of standard molecular weights.

For composition of the diets, see Table 1. 
British Journal of Nutrition Vol. 53, No. 2

Plate 1

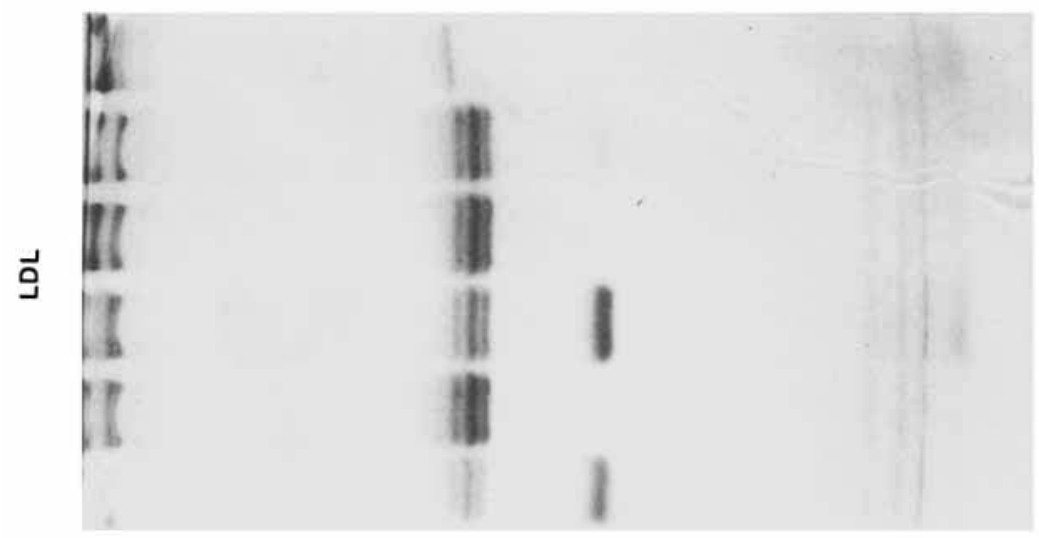

$\square^{\circ}$
$\therefore$
$0^{\circ}$
0
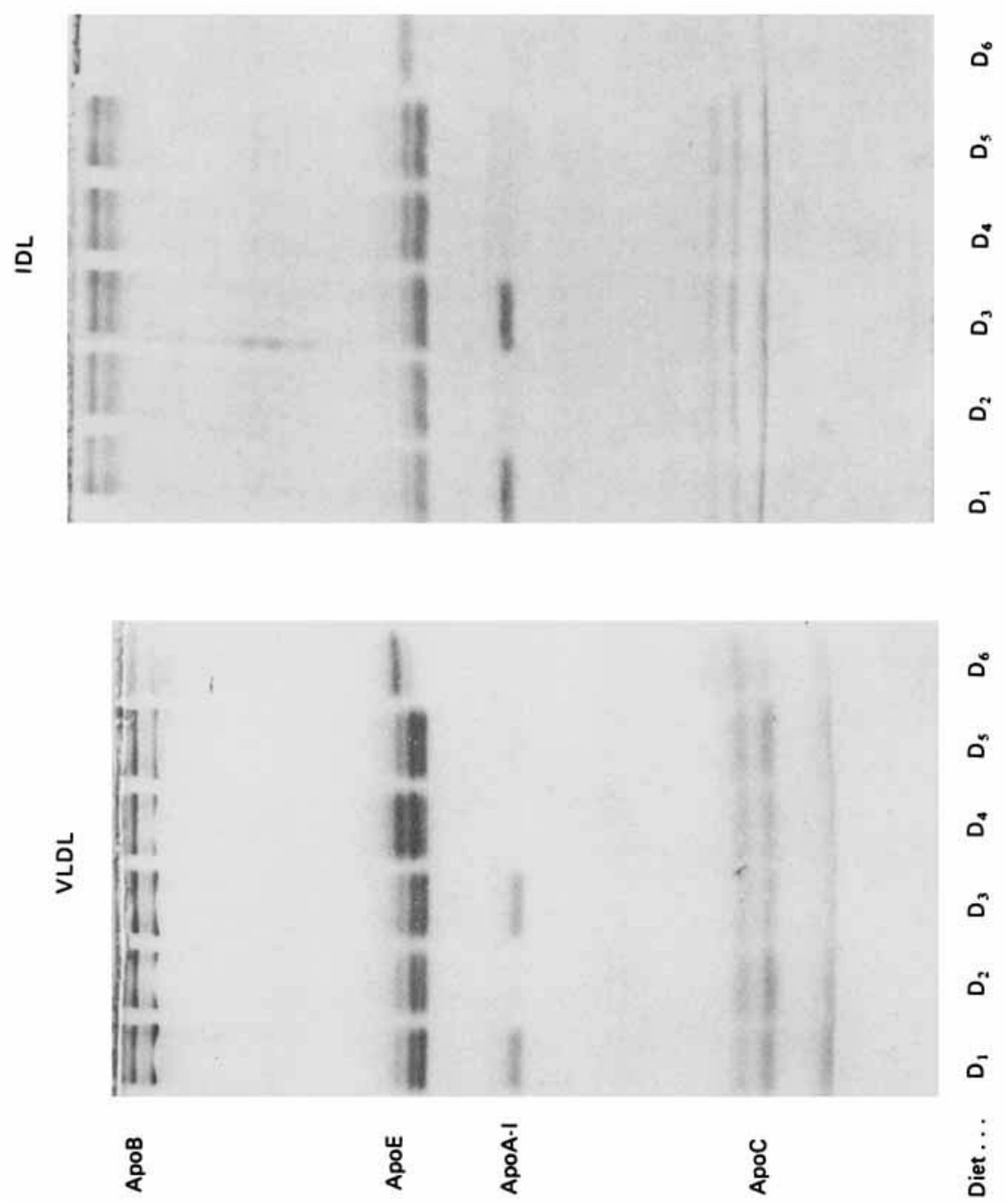

E. MENGHERI AND OTHERS 

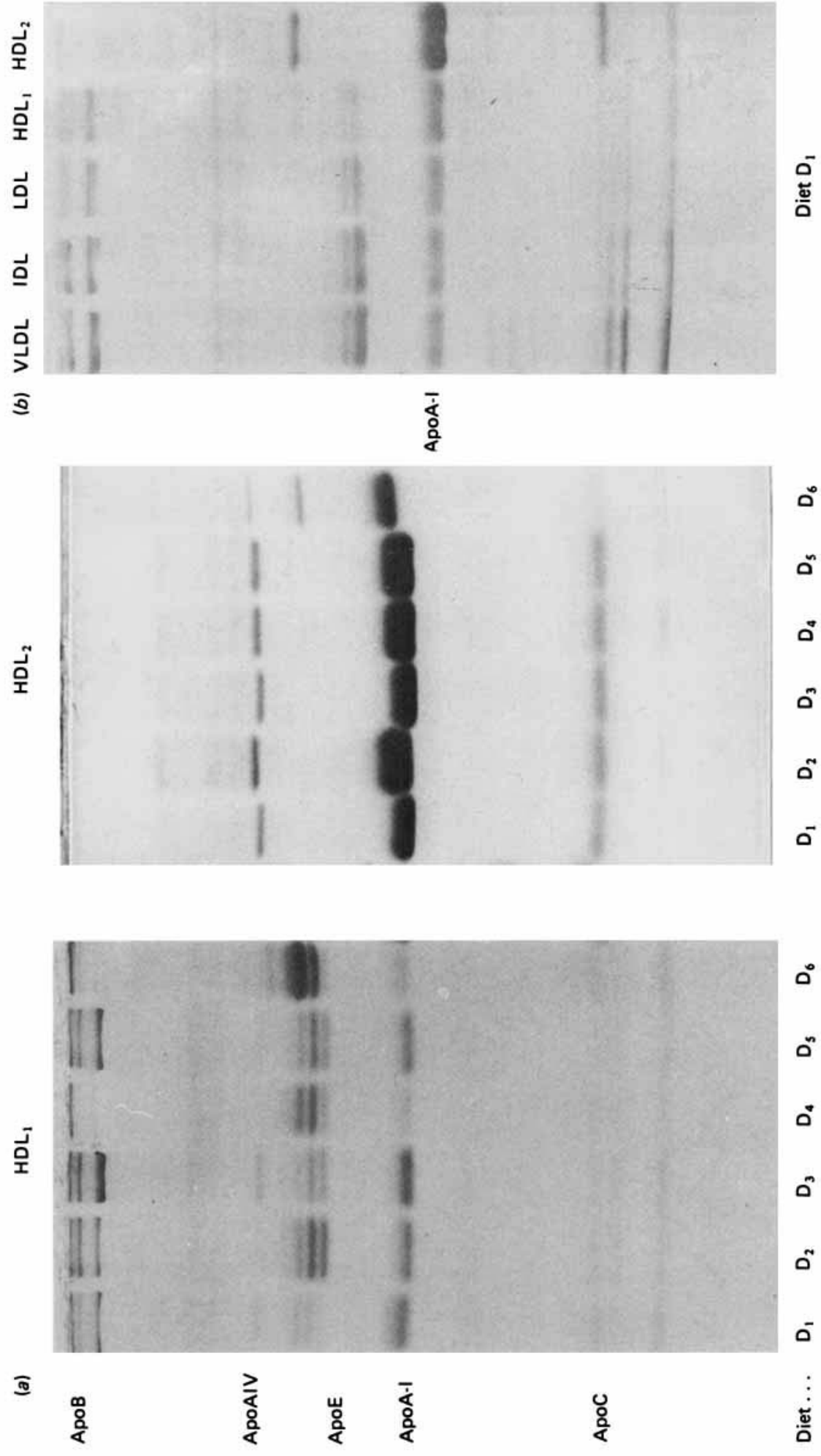